\title{
Discussion of the Factors that Influence the Amazon's Share Prices
}

\author{
Yi Feng ${ }^{1}$, Xujie $\mathbf{L i}^{2}$ \\ ${ }^{1}$ Accounting and Finance, University of Kent, Canterbury, England \\ ${ }^{2}$ School of Science and Engineering, The Chinese University of Hong Kong, Shenzhen. Shenzhen, China
}

Keywords: share prices, Amazon, stock market

\begin{abstract}
The fierce competition of the economic circle sees the active participation in the stock market for more and more global enterprises. Amazon is also included in this trend, in order to obtain its further development and economic profits earning in essence. In order to better understand the role of stock price of Amazon, it is required to focus on the possible factors to impact this enterprise's share prices from different perspectives. Within this study, based on the general condition of this enterprise and the background of the specific information of this company, the emphasis is the previous studies of the factors that influence the Amazon's share prices conducted by different scholars as a matter of fact. This research can lay a solid foundation for the further relevant research about it.
\end{abstract}

\section{Introduction}

The modern society witnesses the fierce competition in the global market, and the majority of enterprises begin to take some strategies to improve their market share and core competitiveness and core values. One effective way to enhance their reputation and profits, the majority of them choose to enter the stock market, to take in numerous investments and make a lot of money. Here, in this paper, the focus will be paid on the stock market of Amazon, the largest online digital business company in America. Established in the year of 1995, it mainly operated the business of books sales at the first time. But presently, it has enlarged its business scope and engaged in many other kinds of products, becoming the most popular online retailer with numerous brands of products and the second largest internet enterprise on the globe. As the powerful online retailer, Amazon tries its best to enter the stock market, for the sake of its tremendous profits and influence as well. In 2018, the stock of Amazon will increase by 30 percent, and it receives the highest profits earning, which means that Amazon attracts more and more investors to purchase its brands and have the optimistic attitude toward this global economy in essence.

In addition, it is known that the stock price of an enterprise does not always remain increasing in total number, and there is no exception of Amazon. The fluctuation of its stock price manifests that it is closely related to many factors, such as the operational condition, trust, development prospect and the stock dividend distribution and the ratios and so on so forth. All these factors can not be avoided by human force. In general, Amazon's stock price is determined by these factors, which can to some extent determine the operational situation of it as a matter of fact. If Amazon has more and more buyers to support its stock, it means that it has the well-established reputation with promising profits and enormous funds. At least, the stock market is a kind of mutual activity to realize the profits in essence. The stock price, from a perspective, can test Amazon's profits earning and occupation of the market share. In this sense, the stock price can not only help Amazon make a lot of potential money but also can enable it to attract more and more investors to support its business in the global market, as well as enlarge its power of influence.

In particular, this research will systematically analyze the factors of influencing the share prices of Amazon, which are Diluted earnings per share (Diluted EPS), price to Book Value (PBV), Revenues of Company (Revenues), Balance of Trade (BOT) and Institute of Supply Management Non-Manufacturing Index (ISMNMI) respectively. The five factors are influential and pose the heavy influence on the share price of the modern enterprises who enter the stock market all the time. 
First of all, the diluted earning per share refers to the impact of potential ordinary share on the real per share, in order to avoid the fake increase of the share and bring the misunderstanding of the information. In the second place, price to book value refers to the pure profits of per share, which can be used to calculate the real value of an enterprise. In the third place, the revenues of company means how much a company impose the taxes to the government, and the higher tax will also influence its share price to some extent. In the fourth place, the balance of trade refers to the balance of the export and import sum in total, which can test whether a company has a better economic performance in the fierce competition, so that it will also evaluate its stock market and its share price. Last but not least, it turns out to be the institutes of supply management non-manufacturing index, which can help decide the company can provide enough products to its consumers, so that it will make enormous profits and have a better result in the stock market. The five variables and elements can be adopted to analyze how Amazon's share price is influenced.

In fact, any enterprise increases and decreases its market price due to their different kinds of reasons, which is a natural rule. All the enterprises should follow this trend and make the most of the market law to deal with their stock market and the profits earning in most cases. Amazon, as the world-level largest book store and the biggest comprehensive online retailer, deserves researching about its share prices and its principal factors from different perspectives.

\section{The research background and significance}

In this part, based on the general understanding of the stock price and the possible influences of influencing Amazon's stock price, it is mainly about the research background and its significance as well, in order to clarify the research objective for this paper.

\subsection{The research background}

In essence, the fluctuation of the share prices is determined by the profits created by the list companies in the long run, but in a short period of time, it is decided by the supply-demand relations. For the latter one, it is influenced by several factors, such as people's prospect of the profits of their chosen companies, the artificial speculation, the total number of the market funds and the factors of policies and so on so forth. According the data, it elaborates that if a company's technical index is lower than the market performance, its stock price will be definitely reduced without any hint. It is usually impacted by the potential economic loss, the ineffective management, the breakdown of the market share and the employee's problem and things like that. Among the influential factors, the diluted earnings per share will be a factor, which is used to evaluate the potential stock and pose some influence to the per share, so as to avoid the misunderstanding of the fake increase.

In consideration of Amazon's stock price, it can be found that its market value surpasses that of Google, and its result has been spread into all walks of life. In recent years, Amazon establishes a new milestone. In recent days, Amazon's market value adds up to 76.8 billion dollars, becoming the second largest enterprise on the globe. As a matter of fact, all the people are familiar with this enterprise, Amazon, since it has a long history with promising and expected performance in the current market. It changes its business from books selling, hardware devices, clouds computation, photography, off-line supermarket, medical insurance, and finance to more and more new fields, which helps it obtain the miraculous economic growth. In the meanwhile, its transformation also makes other companies get panic and nervous, fearing for the lowering of their share prices. In spite of its wonderful performance and profits earning, it also shows that its share prices will also decrease due to some factors. For instance, the fierce competition will cause this result. And in this way, Amazon encounters the fierce competition in this field, so that its total number of consumers will be reduced, so that its share prices will also decease at the same time.

Despite its slight slowdown of share price, Amazon's stock price gradually and continuously increases all the time. According to the data, it means that the frequently increasing stock price is influenced by the following factors, such as the growth of the cloud business service, the growth of the online service sales, the distribution of its stocks, the innovation of its technology, the video 
subscription service and other value-added services in most cases. All these can help explain the reason why Amazon increases its stock price in real occasions. This is the background of this research, aiming to provide enough background information for the audience.

\subsection{The significance of this research}

According to the research of this paper, the study of the factors influencing the Amazon's share prices will help make the depth analysis of the influence of stock prices on its economic performance and encourage Amazon and other companies to have a better understanding of how to make the most of the factors to control the continuous growth of its stock prices, so as to enhance its market share in the current market.

Throughout this research, it can make clear the promising and profitable industries in the modern world, to urge the modern enterprises to grasp the current trend and make money, so that they can improve their stock price. Whether a company operates its business profitably or not can be manifested and reflected by its stock market and share prices as well. The improvement of profits of the companies can stimulate the increase of its stock price. Once it does not have the preferred economic performance, its stock price will simultaneously reduce. This study illustrates that enterprise's performance and profits earning are the principal factor to influence its share price as a matter of fact. Therefore, this research can deepen people's comprehension of the share price and the principal factors that influence their share prices all the time.

Above all, throughout this research, it teaches companies to improve their enterprise's performance and enormous profits based on the considerable market share and the total number of the investors and supporters to a certain degree. Above all, this research is of great importance to explain the specific solutions of how to improve its share price and the major factors influencing its share prices as well. Furthermore, other enterprises will also draw some lessons and learn more experiences to improve their economic performance on the basis of the stock market and its preferable and increasing share prices.

\section{Literature review}

\subsection{The previous research at home}

Chinese scholars also research the factors influencing the stock price from different perspectives. First of all, Fan and Wu (2010) discuss the research of the diluted earnings per share accounting information of the listed companies. The research shows that the diluted earnings per share and the basic earnings per share have the similar and related information with the stock price, and the diluted earnings per share has more decisive usability, which provides the experiences and evidences for the new companies. This is the most important research to address, since it provides a new perspective to help researchers know another factor of influencing the stock market, which turns out to be the diluted earnings per share. Furthermore, Wu and Liang (2008) focus on the influence of stock price in fact. They state that influencing the stock price has a lot of factors, including the interior and exterior elements. Among the factors, they put emphasis on the mental prospect of the investors, which plays an important role in the stock price all the time (Wu \& Liang, 2008). They discover that the stock price is constructed based on the mentality of the investors as a matter of fact.

\subsection{The previous research in foreign countries}

The foreign scholars address the major factors influencing the stock price in the modern market. Leila and Farshid (2014) focus on the study of factors affecting the initial public offering price of the shares on the Tehran stock exchange. The authors mention that the price stocks are the true value of its property and chances for their future economic development and growth (Leila \& Frashid, 2014). In this research, the authors want to address whether pricing the initial offering exchange on Tehran stock exchange is lower than its actual ones and elaborate what elements influence the stock exchange. They adopt the data collection to get the results (Leila \& Farshid, 
2014). The authors get that the offered stock encounters the increased price and in Iran's stock exchange, the price is stabilized with 287 days in total. Moreover, Islam and Arafin (2017) explore that the elements influencing the share price of the cement industry. This is the reason why more and more enterprises around the world enter into the stock market for greater profits as a matter of fact. In addition to the research about the factors to influence the share price in the existing market, there are many other relevant and forceful researches to consolidate this point of view. All these previous studies can provide a lot of theoretical resources for the later researchers.

\section{Research method}

\subsection{Method of data collection}

The purpose of this investigation is to investigate factors that are affecting the share price of Amazon. Therefore, a descriptive research design was adopted. This study is based on the secondary data which were retrieved from "YCharts", "Yahoo Finance", "Bureau of Labor Statistics", "Trading Economics”, and "MacroTrends" websites. The data were collected on market price per share, diluted earnings per share, price to book value, revenues, balance of trade, and Institute of Supply Management Non-Manufacturing Index for the period of 2010-2017.According to limitations, the data of some variables are adjusted and the final data used in the research model are those of each quarter. Table 1 shows the summary of variables in the model and source of data collection.

Table 1. Summary of variables in the model and source of data collection

\begin{tabular}{|c|c|c|c|c|}
\hline Variable & Symbol & Description & Unit & $\begin{array}{l}\text { Source of } \\
\text { Collection }\end{array}$ \\
\hline \multicolumn{5}{|l|}{ Dependent variable } \\
\hline $\begin{array}{l}\text { market price per } \\
\text { share }\end{array}$ & MPS & $\begin{array}{l}\text { average market price per share of five } \\
\text { business days after March 31, June 30, } \\
\text { September 30, and December } 31\end{array}$ & USD & $\begin{array}{c}\text { Website of } \\
\text { "Yahoo Finance" }\end{array}$ \\
\hline \multicolumn{5}{|c|}{ Independent variables } \\
\hline $\begin{array}{l}\text { diluted earnings per } \\
\text { share }\end{array}$ & $\begin{array}{l}\text { Diluted } \\
\text { EPS }\end{array}$ & $\begin{array}{c}\text { Diluted earnings per share trailing twelve } \\
\text { months of March 31, June 30, September } \\
\text { 30, and December } 31\end{array}$ & USD & $\begin{array}{c}\text { Website } \\
\text { of"YCharts" }\end{array}$ \\
\hline price to book value & PBV & $\begin{array}{l}\text { The ratio of "Market price per share" to } \\
\text { "Book value per share" of last day of each } \\
\text { quarter or average S\&P } 500 \text { index of the } \\
\text { business days before and after the last day } \\
\text { of each quarter }\end{array}$ & $\%$ & $\begin{array}{l}\text { Website } \\
\text { of"YCharts" }\end{array}$ \\
\hline Revenues & $\mathrm{RV}$ & $\begin{array}{c}\text { Amazon revenues trailing twelve months } \\
\text { of March 31, June 30, September 30, and } \\
\text { December } 31\end{array}$ & $\begin{array}{l}\text { USD } \\
\text { Billion }\end{array}$ & $\begin{array}{c}\text { Website } \\
\text { of"MacroTrends" }\end{array}$ \\
\hline Balance of trade & BOT & $\begin{array}{l}\text { U.S. balance of trade of March, June, } \\
\text { September, and December }\end{array}$ & $\begin{array}{l}\text { USD } \\
\text { Billion }\end{array}$ & $\begin{array}{l}\text { Website of } \\
\text { “eastmoney” }\end{array}$ \\
\hline $\begin{array}{l}\text { Institute of Supply } \\
\text { Management Non- } \\
\text { Manufacturing } \\
\text { Index }\end{array}$ & $\begin{array}{l}\text { ISMN } \\
\text { MI }\end{array}$ & $\begin{array}{l}\text { Institute of Supply Management Non- } \\
\text { Manufacturing Index of March, June, } \\
\text { September, and December }\end{array}$ & Point & $\begin{array}{l}\text { Website of } \\
\text { "eastmoney” }\end{array}$ \\
\hline
\end{tabular}

Table 2 shows the descriptive statistics for each variable for Amazon and U.S. It is obvious that the market price per share of Amazon ranges from USD.111.962 to USD.1215.76, conducing the average market price per share to USD.432.623. And the diluted earnings per share fluctuates from USD.-0.87 to USD.6.16, conducing the average diluted earnings per share to USD.1.745. Likewise, the price to book value ranges from 8.357 percent to 23.790 percent, leading the average price to book value to 15.689 percent. The revenues of Amazon ranges from USD.26.75billion to 
USD.177.87 billion, leading the average revenues to USD.82.75063 billion. Similarly, the U.S. balance of trade ranges from USD.-50.88billion to USD.-35.536billion, conducing the average unemployment rate to USD. -41.8492 billion. The Institute of Supply Management NonManufacturing Index ranges from 53 points to 59.8 points, leading the average Institute of Supply Management Non-Manufacturing Index to 55.99688 points.

Table 2. Descriptive statistics for the selected variables for Amazon

\begin{tabular}{|c|c|c|c|c|c|}
\hline \multicolumn{7}{|c|}{ Descriptive Statistics } \\
\hline Variables & $\mathrm{N}$ & Minimum & Maximum & Mean & Std. Deviation \\
\hline MPS (in USD) & 32 & 111.962 & 1215.76 & 432.6227656 & 290.2111793 \\
\hline Diluted EPS (in USD) & 32 & -0.87 & 6.16 & 1.745 & 1.868055473 \\
\hline PBV (\%) & 32 & 8.357 & 23.79 & 15.68865625 & 3.913675867 \\
\hline RV(in USD Billion) & 32 & 26.75 & 177.87 & 82.75063 & 40.81137 \\
\hline BOT(in USD Billion) & 32 & -50.88 & -35.536 & -41.8492 & 3.675836 \\
\hline ISMNMI(in Point) & 32 & 53 & 59.8 & 55.99688 & 1.788764304 \\
\hline
\end{tabular}

We also investigate another company eBay which is an e-commerce company as Amazon and the impact of the dependent variables mentioned above on its market price per share. The descriptive statistics are shown in Table 3.

Table 3. Descriptive statistics for the selected variables for eBay

\begin{tabular}{|c|c|c|c|c|c|}
\hline \multicolumn{7}{|c|}{ Descriptive Statistics } \\
\hline Variables & $\mathrm{N}$ & Minimum & Maximum & Mean & Std. Deviation \\
\hline MPS (in USD) & 32 & 8.246 & 39.068 & 22.19988 & 7.970727 \\
\hline Diluted EPS (in USD) & 32 & -0.15 & 6.88 & 2.236563 & 1.821642 \\
\hline PBV (\%) & 32 & 0.7642 & 5.389 & 2.140597 & 1.412604 \\
\hline RV(in USD Billion) & 32 & 8.59 & 16.79 & 11.33063 & 2.755852 \\
\hline BOT(in USD Billion) & 32 & -50.88 & -35.536 & -41.8492 & 3.675836 \\
\hline ISMNMI(in Point) & 32 & 53 & 59.8 & 55.99688 & 1.788764304 \\
\hline
\end{tabular}

In Table 2 and 3 above, it is worth mentioning that both the revenues and market price per share have considerably large standard derivation comparing to those of eBay. This is an evidence for the rapid growth of Amazon. It is also noteworthy to point out that although eBay has market price per share far less than Amazon, it has higher diluted earnings per share.

In this research, multi regression and Pearson statistical torque correlation method as well asT test was used. All this tests and statistical applications were performed by utilizing SPSS.

\subsection{Method of data analysis}

Before performing the linear regression analysis, correlation analysis is required to first inspect the correlation between each pair of variables. This section is necessary because it helps to find the multicollinearity among the independent variables, which can make the t test inefficient. After correlation analysis, for the pairs with index larger than 0.4, the Variance Inflation Factor (VIF) tests should be implemented to see whether there are indeed multicollinearities or not. And the variables that do not pass the VIF test need to be modified or discarded.

The above two steps guarantee that t test is effective. After that, it is essential to define a regression model to describe the impact of independent variables on dependent variable. The general model intended to be employed in our study is manifested on the following equation.

$\mathrm{MPS}=\alpha 0+\alpha 1$ Diluted EPS $+\alpha 2 \mathrm{PBV}+\alpha 3 \mathrm{RV}+\alpha 4 \mathrm{BOT}+\alpha 5 \mathrm{ISMNMI}+\mathrm{e}$ 
Based on the study of previous researches in 2.1, several hypotheses can be developed:H1:There is a positive relationship between MPS and Diluted EPS. H2:There is a positive relationship between MPS and PBV. H3:There is a positive relationship between MPS and RV. H4:There is a negative relationship between MPS and BOT. H5:There is a positive relationship between MPS and ISMNMI.

\section{Result of research}

\subsection{Result of correlation analysis}

For the correlation analysis of variables, the Pearson correlation have been performed and the bivariate Pearson Correlation Coefficients between the market price per share and the independent variables are presented in Table 4.

Table 4. Correlation matrix for dependent and independent variables

\begin{tabular}{|c|c|c|c|c|c|c|}
\hline & MPS & Diluted EPS & PBV & RV & BOT & ISMNMI \\
\hline \multicolumn{7}{|l|}{ Amazon } \\
\hline MPS & 1 & & & & & \\
\hline Diluted EPS & $.692 * *$ & 1 & & & & \\
\hline PBV & $.863 * *$ & $.387 *$ & 1 & & & \\
\hline RV & $.968^{* *}$ & $.529 * *$ & $.871 * *$ & 1 & & \\
\hline BOT & -.318 & $-.463 * *$ & -.036 & -.251 & 1 & \\
\hline ISMNMI & $.529 * *$ & .211 & $.418^{*}$ & $.592 * *$ & -.125 & 1 \\
\hline \multicolumn{7}{|l|}{ eBay } \\
\hline MPS & 1 & & & & & \\
\hline Diluted EPS & $.449 * *$ & 1 & & & & \\
\hline PBV & $.728 * *$ & .247 & 1 & & & \\
\hline RV & -.093 & -.344 & $-.494 * *$ & 1 & & \\
\hline BOT & -1.60 & -.262 & -.087 & .293 & 1 & \\
\hline ISMNMI & $.597 * *$ & .251 & $.452 * *$ & -2.15 & -.125 & 1 \\
\hline
\end{tabular}

Source: SPSS results outcome

**. Correlation is significant at the 0.01 level (2-tailed)

*. Correlation is significant at the 0.05 level (2-tailed).

As discussed in 2.3, if the Pearson Correlation Coefficient is larger than 0.4, then the two variables have a considerable relationship. In Table 4, the data on second column can be ignored because the multicollinearity between dependent variable market price per share and each of the independent variables will have slight effect on the correctness of $t$ test. And for rest of the data shown in Table 4 indicate the strong correlation between several variable pairs: price to book value and diluted earnings per share of Amazon, revenues and diluted earnings per share of Amazon,U.S. balance of trade and diluted earnings per share of Amazon, revenues and price to book value of Amazon, Institute of Supply Management Non-Manufacturing Index and price to book value of Amazon, and revenues of Amazon and Institute of Supply Management Non-Manufacturing Index. The strong correlated pairs of eBay are relatively less: revenues and price to book value of eBay, and Institute of Supply Management Non-Manufacturing Index and price to book value of eBay.

AVIF test conducted to further check the extent of multicollinearity among the independent variables and the results in Table 5 revealed that none of the factors is larger than 10 , thus affirming the absence of any multicollinearity. 
Table 5. VIF test

\begin{tabular}{|c|c|c|}
\hline & VIF of Amazon & VIF of eBay \\
\hline Diluted EPS & 1.704 & 1.220 \\
\hline PBV & 5.309 & 1.614 \\
\hline RV & 7.795 & 1.505 \\
\hline BOT & 1.456 & 1.147 \\
\hline ISMNMI & 1.719 & 1.297 \\
\hline
\end{tabular}

Source: SPSS results outcome

\subsection{Result of regression analysis}

Table 6 below summarizes the most important results of the linear regression analysis: Notice that model 1 is the main model and model $2 \& 3$ are taken to support result of model 1.

Table 6. Estimated result of regression model

\begin{tabular}{|c|c|c|c|c|c|}
\hline \multicolumn{6}{|c|}{ Model 1: Dependent variable - Market Price per Share (MPS) of Amazon } \\
\hline Independent Variables & Coefficient(p value) & $\mathrm{R}^{2}$ & $\mathrm{~F}$ & $\mathrm{p}$ value ( $\mathrm{F}$ test) & Intercept \\
\hline Diluted EPS of Amazon & $40.018(.000 * *)$ & \multirow[t]{5}{*}{0.989} & \multirow[t]{5}{*}{488.318} & \multirow[t]{5}{*}{$.000 * *$} & \multirow{5}{*}{-334.468} \\
\hline PBV of Amazon & $13.447\left(.001^{* *}\right)$ & & & & \\
\hline RV of Amazon & $4.744\left(.000^{* *}\right)$ & & & & \\
\hline BOT & $-1.944(.320)$ & & & & \\
\hline ISMNMI & $.221(.959)$ & & & & \\
\hline \multicolumn{6}{|c|}{ Model 2: Dependent variable - Market Price per Share (MPS) of Amazon } \\
\hline Independent Variable & Coefficient(p value) & $\mathrm{R}^{2}$ & F & p value ( $\mathrm{F}$ test) & Intercept \\
\hline MPS of eBay & $33.148\left(.000^{* *}\right)$ & .829 & 145.302 & $.000^{* *}$ & -303.261 \\
\hline \multicolumn{6}{|c|}{ Model 3: Dependent variable - Market Price per Share (MPS) of eBay } \\
\hline Independent Variables & Coefficient(p value) & $\mathrm{R}^{2}$ & $\mathrm{~F}$ & p value ( $\mathrm{F}$ test) & Intercept \\
\hline Diluted EPS & $1.354(.002 * *)$ & \multirow[t]{5}{*}{0.819} & \multirow[t]{5}{*}{23.457} & \multirow[t]{5}{*}{$.000^{* *}$} & \multirow[t]{5}{*}{-83.345} \\
\hline PBV & $4.215\left(.000^{* *}\right)$ & & & & \\
\hline $\mathrm{RV}$ & $1.376\left(.000^{* *}\right)$ & & & & \\
\hline BOT & $-.259(.193)$ & & & & \\
\hline ISMNMI & $1.197(.009 * *)$ & & & & \\
\hline
\end{tabular}

Source: SPSS results outcome

**. Correlation is significant at the 0.01 level (2-tailed).

*. Correlation is significant at the 0.05 level (2-tailed).

In Table 6, model 1 is the linear regression model with dependent variable and independent variables related to Amazon. The second model investigate the relationship between dependent variable: MPS of Amazon and independent variable: MPS of eBay. Model 3 is the linear regression model with dependent variable and independent variables related to eBay.

The result of regression model 1 and 3 in Table 6 shows: Diluted earnings per share: at the meaning level of $1 \%$ and the coefficient also shows a positive effect on market price per share of Amazon, so as the value of eBay. Therefore, the first hypothesis is confirmed. This result is similar to previous researches about the correlation between earnings per share and share price. Price to book value: at the meaning level of $1 \%$ and the coefficient shows a positive effect on market price per share of Amazon. And the p value and coefficient of eBay are also in accordance with the second hypothesis. Revenues of company: at the meaning level of $1 \%$ and the coefficient also shows a positive effect on market price per share of Amazon. The correctness of the third hypothesis is also supported by the $\mathrm{p}$ value and positive coefficient of eBay. Balance of trade: notice that the $\mathrm{p}$ value of both Amazon and eBay are too large to confirm the proposed relation between market price per share and the U.S. balance of trade. And this variable is very weak effect in determining market price per share of Amazon. The same conclusion can be drawn from the 
correlation matrix in Table 4: the balance of trade does not have strong relationships with both share price of Amazon and eBay. Hypothesis 4 is rejected.

Institute of Supply Management Non-Manufacturing Index: as for this independent variable, the result of Amazon is inconsistent with that of eBay. For Amazon, the p value is nearly 1 while that $p$ value of eBay is at the meaning level of $1 \%$.Combining the regression model result of Amazon with that of eBay, the impact of Institute of Supply Management Non-Manufacturing Index on share price of Amazon seems ambiguous. However, taking result of regression model 2 into consideration, the variables that affect eBay share price should have the same effect on Amazon share price. In addition, Institute of Supply Management Non-Manufacturing Index is a crucial factor that influencing e-Commerce company share price. Moreover, the large $\mathrm{p}$ value of ISMNMI in regression model 1 may be resulted from the inaccuracy of data, because are collected quarterly and only 32 data for each variable for 8 years period. In a word, ISMNMI should be a meaningful factor for Amazon share price.

The result of regression model 2 shows a substantial correlation between share price of Amazon and eBay. The p value of eBay MPS is of $1 \%$ significance, which is a strong evidence for the similarity between the two companies.

\section{Conclusion and Prediction}

\subsection{Conclusion}

The correctness of our regression model can be verified in following aspects:

(1). F test: Table 6 reveals that the p value of $F$ test is at the significance level of $1 \%$, which means that in very rare case the model has coefficients all equal to zero. In other words, the null hypothesis of F test is rejected. The regression model is effective. (2). R2: in Table 6, the R2 of model 1 is 0.989 and this is to say the independent variables can explain $98.9 \%$ of the dependent variable. Thus the regression model is efficient in representing and predicting dependent variable. (3). Pearson correlation test: in Table 4, except for the balance of trade, other independent variables have strong relationship with the dependent variable. (4). Model $2 \& 3$ : model 2 confirms the high similarity between Amazon share price and eBay share price. Model 3 shows the investigated regression model fit the eBay case well, and this is an evidence for the effectiveness of the model for Amazon.

Let the market price share be $\mathrm{Y}$, diluted earnings per share be $\mathrm{X} 1$, price to book value be $\mathrm{X}$, revenues of Amazon be X3, U.S. balance of trade be X4, and the Institute of Supply Management Non-Manufacturing Index be X5, then based on the study above we have:

$\mathrm{Y}=\alpha_{0}+\alpha_{1} \mathrm{X}_{1}+\alpha_{2} \mathrm{X}_{2}+\alpha_{3} \mathrm{X}_{3}+\alpha_{4} \mathrm{X}_{4}+\alpha_{5} \mathrm{X}_{5}$, where $\alpha_{0}$ is a constant.

According to Table $6, \alpha_{0}=-334.468, \alpha_{1}=40.018, \alpha_{2}=13.447, \alpha_{3}=4.744, \alpha_{4}=-1.944, \alpha_{5}=0.221$. Therefore, $Y=$ $334.468+40.018 \mathrm{X}_{1}+13.447 \mathrm{X}_{2}+4.744 \mathrm{X}_{3}-1.944 \mathrm{X}_{4}+0.221 \mathrm{X}_{5}$.

It is also noteworthy to mention that results of model $1 \& 3$ imply diluted earnings per share, price to book value, and the revenues of the company are the common factors that influence the ecommerce companies' share price like Amazon and eBay.

\subsection{Prediction}

According to the regression formula aforementioned as well as the data for diluted earnings per share of Amazon, price to book value of Amazon, revenues of Amazon, U.S. balance of trade, and Institute of Supply Management Non-Manufacturing Index of the 2018's first quarter, the market price per share calculated for the market price per share is 1343.01731 . This value is very close to market price per share of first business day after first quarter, which is 1,371.99.

The implication of this study suggests a rational investor's need to consider diluted earnings per share, price to book value, revenues, and Institute of Supply Management Non-Manufacturing Index before making investment decisions. Also, the results reveal the common factors that influence the e-commerce companies' share price. 


\section{References}

[1] Sharif T, Purohit H, Pillai R. Analysis of Factors Affecting Share Prices: The Case of Bahrain Stock Exchange[J]. International Journal of Economics and Finance, 2015, 7(3): 207.

[2] Ghose A K, Chowdhury M S. Determinants of Share Prices in Bangladesh: Evidence from Pharmaceuticals Industry[J]. JOURNAL OF BUSINESS STUDIES, 2016, 9: 117.

[3] Hinz O, Nofer M, Schiereck D, et al. The influence of data theft on the share prices and systematic risk of consumer electronics companies[J]. Information \& Management, 2015, 52(3): 337-347.

[4] Ishida S, Kanagawa S. Identification of Jump Times of Large Jumps for the Nikkei 225 Stock Index from Daily Share Prices via a Stochastic Volatility Model[J]. Theoretical and Applied Mechanics Japan, 2015, 63: 109-116.

[5] Iqbal A, Ahmed F, Zaidi S S Z, et al. Determinants of share prices, evidence from Oil and Gas and Cement sector of Karachi Stock Exchange (A Panel Data Approach)[J]. Journal of Poverty, Investment and Development, 2015, 8(1): 14-19.

[6] Almumani M A. Determinants of equity share prices of the listed banks in Amman stock exchange: Quantitative approach[J]. International Journal of Business and Social Science, 2014, 5(1): 91-104.

[7] Gay R D. Effect of macroeconomic variables on stock market returns for four emerging economies: Brazil, Russia, India, and China[J]. The International Business \& Economics Research Journal (Online), 2016, 15(3): 119.

[8] Campbell G, Quinn W, Turner J D, et al. What moved share prices in the nineteenth - century London stock market?[J]. The Economic History Review, 2018, 71(1): 157-189.

[9] Sayed A, Auret C, Page D. Do share prices lead economic activity in emerging markets? Evidence from South Africa using Granger-causality tests[J]. Investment Analysts Journal, 2017, 46(3): 200-212.

[10] Van Staden C. The influence of corporate social responsibility disclosure on share prices[J]. Pacific Accounting Review, 2015, 27(2): 208-228.

[11] Metghalchi M, Chen C P, Hayes L A. History of share prices and market efficiency of the Madrid general stock index[J]. International Review of Financial Analysis, 2015, 40: 178-184.

[12] Chung T, Ariff M. A test of the linkage among money supply, liquidity and share prices in Asia[J]. Japan and the World Economy, 2016, 39: 48-61. 